\title{
Anticancer Activity of Vernonia amygdalina Del. Extract on WiDr Colon Cancer Cell Line
}

\author{
Ramadhan Bestari ${ }^{1}$, M. Ichwan ${ }^{2}$ \\ Department of Pharmacology \\ Faculty of Medicine, Universitas Sumatera Utara \\ Medan, Indonesia \\ bk44ab@gmail.com,mhd.ichwan@gmail.com
}

\author{
Mustofa $^{3}$ \\ Department of Pharmacology \\ Faculty of Medicine, Gadjah Mada University \\ Yogyakarta, Indonesia \\ mustofafk@ugm.ac.id
}

\author{
Denny Satria ${ }^{4}$ \\ Department of Pharmaceutical Biology \\ Faculty of Pharmacy, Universitas Sumatera Utara \\ Medan, Indonesia \\ denny.satria.dennysatria@gmail.com
}

\begin{abstract}
Colon cancer is the third most common cancer in men and second in women. Cancer treatments include chemotherapy, but some chemotheraphy drugs are resistant. Vernonia amygdalina Del. is one of the most widely reported plant that can inhibit the growth of various cancer cell lines. This study aims to examine the anticancer activity of Vernonia amygdalina Del. extract on WiDr colon cancer cell line. This research is an experimental research in vitro using posttest only control group design. Research subjects are WiDr cells. The research method starts from preparation and characterization of simplicia, gradual maceration of Vernonia amygdalina Del. using n-hexane, ethyl acetate, and ethanol, phytochemical analysis of each extracts, cytotoxicity assay on WiDr cells using MTT (Microculture Tetrazolium Technique) assay. Ethyl acetate extract of Vernonia amygdalina Del. has the lowest $\mathrm{IC}_{50}$ value in cytotoxicity assay results, indicate that ethyl acetate extract has very strong citotoxic activity on WiDr cells. Further studies are to analysis the mechanisms of ethyl acetate extracts in induce apoptosis, inhibition of cell cycle, and to observe the protein expression associated with it.
\end{abstract}

Keywords - cytotoxicity; Vernonia amygdalina Del.; WiDr cells; MTT assay

\section{INTRODUCTION}

Colon cancer is the third largest incidence of malignancy in men and second in women with new cases of 1.4 million and as the cause of 693,600 deaths in 2012 worldwide [1]. Colon cancer treatment includes surgery, radiotherapy, and chemotherapy depending on the stage of the patient. Chemotherapy is often used as the main therapy to overcome advanced grade of colon cancer [2].

A number of chemotherapy drugs are reported to be resistant in treating colon cancer [3]. To overcome this problem it is necessary to develop a new drugs that can overcome chemotherapy resistance or potentially as a new chemotherapy drugs in the treatment of colon cancer. Many natural compounds derived from plants have cytotoxic activity against cancer cells [4]. One of them is Vernonia amygdalina Del. that has cytotoxic activity against some cancer cells [5].

In vitro method, this is a preliminary study that can be performed to analysis the anticancer activity of a compound [6]. The WiDr cells is one model of colon cancer cell that is often used in vitro research, isolated from a colon of a 78year-old woman with a type of adenocarcinoma [7]. Adenocarcinoma is a type of cancer that develops in glandular cells where almost $96 \%$ of colon cancer is an adenocarcinoma [8]. Based on the explanation, researcher is interested to extraction of Vernonia amygdalina Del. using gradual maceration method to separate the active compounds that are efficacious as anticancer based on polarity to WiDr cells using cytotoxicity assay methods.

\section{MATERIALS AND METHODS}

\section{A. Preparation of Plant Material and Simplicia}

Vernonia amygdalina Del. Was obtained from Medicinal Plant Garden at Faculty of Pharmacy, Universitas Sumatera Utara, Jl. Tridharma Universitas Sumatera Utara Medan, North Sumatera, Indonesia. Vernonia amygdalina Del. identified by Herbarium Medanense (MEDA), Universitas Sumatera Utara, Medan. Vernonia amygdalina Del. then dried with a drying cabinet at a temperature of 40-60 celcius degree until it reaches a water content below $10 \%$. The dried simplicia is blended into a powder, then weighed, put in a plastic container, and kept at room temperature.

\section{B. Characterization of Simplicia}

Characterization of simplicia is includes macroscopic examination, microscopic examination, water content value, water soluble extractive value, ethanol soluble extractive value, total ash value, and acid soluble ash value which is performed according with standard procedures [9].

\section{Preparation of Crude Extract}

A total of 100 parts of the simplicia are inserted into the dark vessel, macerated with n-hexane as much as 75 parts, 
then closed and left for 5 days protected from light, often stirred. After 5 days, the solution is filtered and the dregs are washed with solvent to get 100 parts. The solution is accommodated on a dark bottle, left in a cool place and protected from light for 2 days. Then filtered and evaporated with rotary evaporator and freeze dryer. The powder is dried and macerated again with ethyl acetate and ethanol [10].

\section{Phytochemical Analysis}

Phytochemical analysis of n-hexane, ethyl acetate, and ethanol extracts was performed to obtain secondary metabolite information dissolved in each extract with different polarities. The secondary metabolites tested were alcaloids, flavonoids, saponins, glycosides, tannins, terpenes, and steroids [11].

\section{E. Preparation of Crude Extract Stock Solution}

The crude extract was weighed at 5 milligrams, followed by taking DMSO to 5 milliters (concentration of the solution are 1 milligrams per milliters) and stored as stock solution for subsequent use in the study. The cytotoxic concentration of the extract was diluted by using culture medium.

\section{F. Cell Culture}

In this study, WiDr cells were obtained from the Laboratory of Parasitology, Faculty of Medicine, Gadjah Mada University were grown in RPMI medium containing $10 \%$ Fetal Bovine Serum (Gibco, USA), 2\% PenicillinStreptomycin (Gibco, USA), and Fungizone (Amphotericin B) $0.5 \%$ (Gibco, USA) on the flask in a humidified incubator $\left(5 \% \mathrm{CO}_{2} / 95 \%\right.$ air) at 37 celcius degree.

\section{G. Citotoxicity Assay}

The viability of WiDr cells was assessed using the MTT assay. The cells were cultivated on 96 well plates (Iwaki, Japan). Each well contains $1 \times 10^{4}$ cells. The cells were incubated in a humidified incubator $\left(5 \% \mathrm{CO}_{2} / 95 \%\right.$ air $)$ for 24 hours. After 24 hours incubation, the medium culture is discharged and each extract are dissolved with a concentration of 500, 250, 125, 62.5, and 31.25 micrograms per milliters. After 24 hours incubation, the cells were incubated with 0.5 milligrams per milliliters MTT (Sigma-Aldrich, USA) for 4 hours at 37 celcius degree. The cells that is feasible to react with MTT to produce of purple crystals formazan. After 4 hours, 10\% SDS (Sigma-Aldrich, USA) stopper in 0.01 Moles $\mathrm{HCl}$ (Merck, USA) was added to dissolve the formazan crystals. Then, the cells were incubated for 24 hours at room temperature and protected from light. After incubation, cells were shaken, and cell absorbance was measured by microplate reader (Bio-Rad, USA) at $\lambda 595$ nanometers. The experimental data is the absorbance of each well, and then converted to percentage of a cells viable using equation as indicated below

$$
\% \text { of vrable cells }=\frac{\mathrm{B}-\mathrm{C}}{\mathrm{A}-\mathrm{C}} \times 100 \%
$$

Where A, B, and C (1) respectively are absorbance of control cells absorbance, treated cells absorbance, and medium culture absorbance. All data were expressed as $\mathrm{IC}_{50}$ that calculate using probit regression analysis at SPSS 20 with $\mathrm{p}$ values $<0.05$ were considered significant [12].

\section{RESULT}

\section{A. Characterization of Simplicia}

Macroscopic examination is includes examination of shape, color and taste. Macroscopic examination of Vernonia amygdalina Del. fresh that has an oval-ellipse shape, tip and base of tapered leaves, pinnate bone fringe, jagged leaf edge and rough, very smooth hair surface, length $15 \mathrm{~cm}-19 \mathrm{~cm}$, width $5 \mathrm{~cm}-8 \mathrm{~cm}$, light green color, and taste bitter followed by sweet taste.

Microscopic examination of Vernonia amygdalina Del. simplicia are found multicellular cover hair, calcium oxalate crystals in the form of prism and rosette, amilium in aqueous media, anomocytic stomata, and palisade tissue.

The result of water content value, water soluble extractive value, ethanol soluble extractive value, total ash value, and acid soluble ash value of Vernonia amygdalina Del. simplicia can be seen in Tabel I.

\section{TABLE I. SIMPLICIA CAHARACTERIZATION RESULT}

\begin{tabular}{|l|c|}
\hline \multicolumn{1}{|c|}{ Parameter } & Result (\%) \\
\hline Water content value & 7,98 \\
\hline Water soluble extractive value & 25,89 \\
\hline Ethanol soluble extractive value & 14,89 \\
\hline Total ash value & 9,74 \\
\hline Acid insoluble ash value & 0,70 \\
\hline
\end{tabular}

\section{B. Phytochemical Analysis}

The results of phytochemical analysis of n-hexane extract, ethyl acetate extract, and ethanol extract are shown in Table II.

TABLE II. PHYTOCHEMICAL ANALYSIS OF VERNONIA AMYGDALINA DEL.EXTRACT

\begin{tabular}{|l|c|c|c|}
\hline \multirow{2}{*}{\multicolumn{1}{|c|}{$\begin{array}{c}\text { Metabolite } \\
\text { Compound }\end{array}$}} & \multicolumn{2}{c|}{ Vernonia amygdalina Del. extract } \\
\cline { 2 - 4 } & $n$-hexane & ethyl acetate & ethanol \\
\hline Alkaloids & - & - & - \\
\hline Flavonoids & - & + & + \\
\hline Glycosides & - & + & + \\
\hline Saponins & - & + & + \\
\hline Tanins & - & - & + \\
\hline Terpenes & + & + & + \\
\hline Steroids & + & + & + \\
\hline
\end{tabular}

\section{Cytotoxicity Assay}

Cytotoxic assay is a preliminary test to determine the potential toxicity of a compound and $\mathrm{IC}_{50}$ as a mainly parameters. Fig. 1, Fig. 2, and Fig. 3 shows the effect of extract log concentration that expressed as micrograms per milliters $(\mu \mathrm{g} / \mathrm{mL})$ to percentage of WiDr cells viability $(\%)$. 


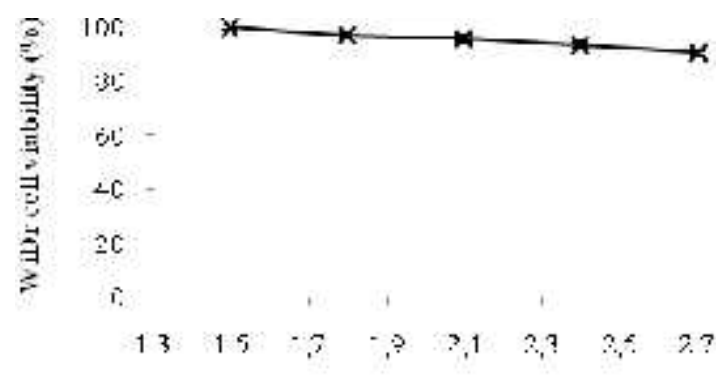

A-hesane extract log, concentration (II $\mathrm{g} / \mathrm{mL})$

Fig. 1. Graph of n-hexane extract log concentration on WiDr cell viability

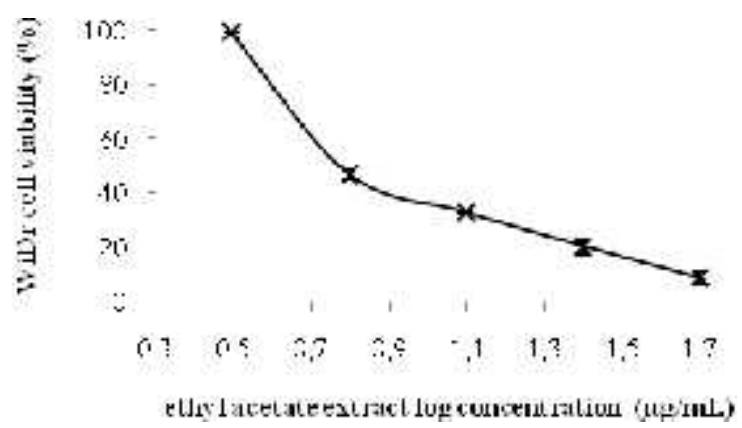

Fig. 2. Graph of ethyl acetate extract log concentration on WiDr cell viability

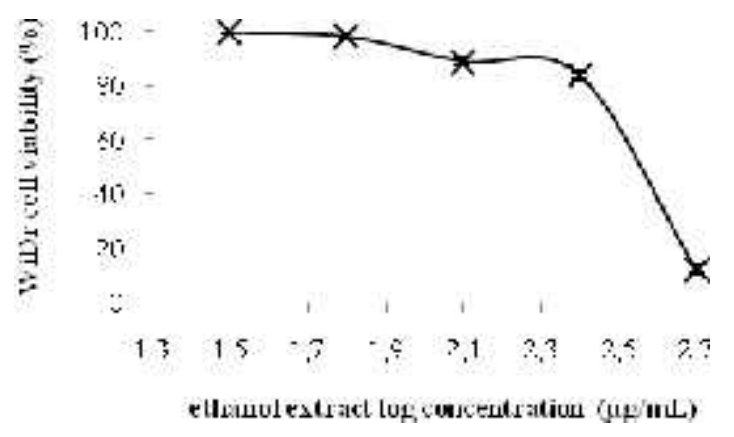

Fig. 3. Graph of ethanol extract log concentration on WiDr cell viability

Based on Fig. 1, Fig. 2, and Fig. 3, the cytotoxic activity on WiDr cells is indicated by $\mathrm{IC}_{50}$ value of each extract in Table III which is calculated using probit regression analysis. $\mathrm{IC}_{50}$ is the $50 \%$ half maximal inhibitory activity expressed in micrograms per milliters $(\mu \mathrm{g} / \mathrm{mL})$.

TABLE III. $\quad$ IC $_{50}$ VALUE OF EACH EXTRACT

\begin{tabular}{|l|c|}
\hline \multicolumn{1}{|c|}{ Extract } & IC $_{\mathbf{5 0}}$ value $^{\text {a }}(\boldsymbol{\mu g} / \mathbf{m L})$ \\
\hline n-hexane & $7934.963 \pm 4154.833$ \\
\hline ethyl acetate & $9.086 \pm 0.431$ \\
\hline ethanol & $321.131 \pm 9.902$ \\
\hline
\end{tabular}

\section{DISCUSSION}

The aims from characterization of simplicia is to control the quality of simplicia so as to obtain standardization from simplicia. The standardization of simplicia has the understanding that the simplicia to be used as a raw material must meet certain requirements [13]. Standardization of simplisia Vernonia amygdalina Del. has not been established in the Indonesian Herbal Pharmacopoeia, but there are some provisions concerning the characterization of simplicia that must be met in order for simplicia to be used as a raw material for drug development [14]. On examination of water content value from Vernonia amygdalina Del. simplicia get results of $7.98 \%$. Water content value of simplicia that exceeds $10 \%$ can be a good medium for microbial growth, presence of fungi or insects, and encourage damage due to hydrolysis process [15].

Water soluble extractive value get results of $25.89 \%$, while ethanol soluble extractive value get results of $14.89 \%$. The determination of water soluble extractive value is to know the level of polar chemical compound contained in simplicia, while determination of ethanol soluble extractive value is determine the level of soluble compound in ethanol, both polar and non polar compounds. The water soluble extractive value of the extract is greater than the ethanol soluble extractive value because the polar compound is more soluble in the water than ethanol solvent, and the unsoluble compound in the water solvent will dissolves in the ethanol solvent. Water can dissolve other unnecessary substances such as gums, starches, proteins, fats, mucus etc., this is that causes the high levels of water soluble extractive value from the simplicia [16]. Total ash value get results of $9.74 \%$ and acid insoluble ash value get results of $0.70 \%$. The determination of total ash value is intended to determine the internal mineral content (physiological ash) derived from the plant tissue itself, and external (non-physiological ash) which is the residue from the outside such as sand and soil contained in the sample [17]. The results of the determination of the total ash value is quite high due to the heavy content of heavy metals contained in Vernonia amygdalina Del. such as $\mathrm{Fe}, \mathrm{Zn}, \mathrm{Pb}$, and $\mathrm{Cr}$ [18].

The results of phytochemical analysis were used as a reference to identify which class of secondary metabolite compounds have cytotoxic activity against WiDr cells. Secondary metabolites found in n-hexane extract are terpens and steroids. In ethyl acetate extract are flavonoids, glycosides, saponins, terpens, and steroids. In ethanol extracts are flavonoids, glycosides, saponins, tannins, terpens and steroids. Flavonoids and sesquiterpene lactones are secondary metabolite compounds that are known to have cytotoxic activity thus indicating that Vernonia amygdalina Del. this is potentially as an anticancer [19]. Secondary metabolite compounds found in Vernonia amygdalina Del. are stigmastane-type saponins (vernoniosides A1, A2, A3, A4, B1, B2, B3, C, D, E), steroidal saponins, sesquiterpene lactones (vernolide, vernodalol, vernolepin, vernodaline, vernomygdin, hydroxyvernolide), flavonoids (luteolin, luteolin 7-O- $\beta$-glucoroniside, luteolin 7-O- $\beta$-glucoside), coumarin, phenolic acids, lignans, xanthones, terpenes, peptides, anthraquinones, and edoties (peptides) [20].

In the cytotoxic assay results were found $\mathrm{IC}_{50}$ of $\mathrm{n}$-hexane extract, ethyl acetate extract, and ethanol extract respectively are 7934,963 $\pm 4154,833$ micrograms per milliters, 9,086 \pm 
0.431 micrograms per milliters, and 321,131 $\pm 9,902$ micrograms per milliters. Ethyl acetate extract has very strong cytotoxic activity, ethanol extract has moderate cytotoxic activity, whereas n-hexane extract has no cytotoxic activity. An extract can be said to has very strong cytotoxic activity when $\mathrm{IC}_{50}$ values below 10 micrograms per milliters, strong cytotoxic activity if $\mathrm{IC}_{50}$ values $10-100$ micrograms per milliters, and moderate cytotoxic activity if $\mathrm{IC}_{50}$ value 100 500 micrograms per milliters [21].

Epivernodalol that is compounds of the sesquiterpene lactones has cytotoxic activity on HCT-15 colon cancer cells, HT-29 colon cancer cells, HT-144 colon cancer cells, SiHa cervical cancer cells, and T47D breast cancer cells [22, 23]. Vernolide-A that is another compound of the sesquiterpene lactones has cytotoxic activity on B16F-10 melanoma cells by increasing the expression of apoptotic-promoting proteins and suppressing the expression of antiapoptotic protein, and also suppressing the expression of NF- $\kappa \mathrm{B}$ family [24]. Luteolin that is compounds of the flavonoid has cytotoxic activity on HCT-15 colon cancer cells by increasing production of ROS (reactive oxygen species) intracellular which will then lead to fragmentation of DNA [25].

$\mathrm{NF}-\kappa \mathrm{B}$ family is activated on $\mathrm{WiDr}$ cells and the expression at a fairly high level [26]. Activation of the NF- $\kappa B$ family can cause gene transcription of cancer cells that play a role in promoting proliferation, inhibiting apoptosis, increasing inflammation, increasing angiogenesis, and promoting tumor promotion and metastasis. The NF- $\kappa \mathrm{B}$ family is a transcription factor of genes that play a role in inhibiting apoptosis such as the Bcl-2 family, and genes that play a role in causing tumor and metastatic promotion such as COX-2, so that suppression of NF- $\mathrm{kB}$ family expression plays a role in stimulating cells to undergo apoptosis [27]. Increased ROS intracellular may cause cell cycle inhibition and activation of apoptosis pathway [28]. WiDr cells have a mutation of p53 at codon $273 \mathrm{G} \rightarrow \mathrm{A}$ that the change of residual of arginine become histidin [29]. Suppression of mutant p53 expression may also induce cells to undergo apoptosis [30].

Apoptosis can occur either through external factors (extrinsic pathways) or due to mitochondrial stress (intrinsic pathway). Both the extrinsic and intrinsic pathways will end up at the execution phase point that is considered the apoptotic pathway, which begins with sequential activation of the caspase protein (cascade caspase) that activates the cytoplasmic endonucleases, then degrades the core body, and activates proteases that degrade the core and cytoskeletal proteins [31]. Caspase cascade plays a very important role in the process of apoptosis, either through extrinsic pathways or intrinsic pathways that are considered the final pathway of apoptosis [32].

\section{CONCLUSION}

Vernonia amygdalina Del has cytotoxic activity on WIDr cells caused by secondary metabolites such as sesquiterpene lactones and flavonoids that is contains. From the results of cytotoxicity assay was conclude that ethyl acetate extract has the strongest cytotoxic activity compared with ethanol extract and n-hexane extract. It is recommend to conduct further research to analysis the mechanisms of ethyl acetate extract in induce apoptosis, inhibition of cell cycle, and to observe the expression of the proteins associated with it.

\section{ACKNOWLEDGMENT}

Thanks to the staff of the Parasitology Laboratory, Gadjah Mada University, Yogyakarta who has assisted this research until finish. May all of your help will be rewarded from Allah Almighty.

\section{REFERENCES}

[1] J. Ferlay, et al., "Cancer incidence and mortality worldwide: sources, methods and major patterns in GLOBOCAN 2012," International Journal of Cancer, vol. 136, pp. E359-E386, 2015.

[2] C. E. DeSantis, et al., "Cancer treatment and survivorship statistics, 2014," CA: A Cancer Journal for Clinicians, vol. 64, pp. 252-271, 2014.

[3] W. A. Hammond, A. Swaika, and K. Mody, "Pharmacologic resistance in colorectal cancer: a review," Therapeutic Advances in Medical Oncology, vol. 8, pp. 57-84, 2016.

[4] N. Agarwal, C. Majee, and G. Chakraborthy, "Natural herbs as anticancer drugs," International Journal of PharmTech Research, vol. 4, pp. 142-153, 2012.

[5] N. J. Toyang, et al., "In vitro anti-prostate cancer and ex vivo antiangiogenic activity of Vernonia guineensis Benth. (Asteraceae) tuber extracts," Journal of Ethnopharmacology, vol. 141, pp. 866-871, 2012.

[6] B. A. Teicher, Anticancer drug development guide: preclinical screening, clinical trials, and approval. New York: Springer Science \& Business Media, 1997.

[7] T. Chen, D. Drabkowski, R. Hay, M. Macy, and W. Peterson, "WiDr is a derivative of another colon adenocarcinoma cell line, HT-29," Cancer Genetics and Cytogenetics, vol. 27, pp. 125-134, 1987.

[8] S. L. Stewart, J. M. Wike, I. Kato, D. R. Lewis, and F. Michaud, "A population-based study of colorectal cancer histology in the United States, 1998-2001," Cancer, vol. 107, pp. 1128-1141, 2006.

[9] I. Sari, "The characterization of simplisia, isolation and identification of chemical constituens from thallus Turbinaria decurrens Bory," Jurnal Natural, vol. 15, pp. 19-27, 2015.

[10] M. Furqan, S. Hadisahputra, and Rosidah, " Effects of inhibition cell cycle and apoptosis of poguntano leaves ethylacetate extract (Picria felterrae Lour.) on breast cancer cells," International Journal of PharmTech Research, vol. 6, no. 3, pp. 1096-1099, 2014.

[11] A. M. Ismail, E. A. Mohamed, M. R. Marghany, F. F. Abdel-Motaal, I. B. Abdel-Farid, and M. A. El-Sayed, "Preliminary phytochemical screening, plant growth inhibition and antimicrobial activity studies of Faidherbia albida legume extracts," Journal of the Saudi Society of Agricultural Sciences, vol. 15, pp. 112-117, 2016.

[12] E. Meiyanto, R. A. Susidarti, S. Handayani, and F. Rahmi, "Ekstrak etanolik biji buah pinang (Areca catechu L.) mampu menghambat proliferasi dan memacu apoptosis sel MCF-7," Majalah Farmasi Indonesia, vol. 19, pp. 12-19, 2008.

[13] M. Salim, N. Sulistyaningrum, A. Isnawati, H. Sitorus, Y. Yahya, and T. Ni'mah, "Simplisia dan ekstrak kulit buah duku (Lansium domesticum Corr.) dari provinsi Sumatera Selatan dan Jambi," Jurnal Kefarmasian Indonesia, vol. 6, pp. 117-128, 2016.

[14] H. R. Dewoto, "Pengembangan obat tradisional Indonesia menjadi fitofarmaka," Majalah Kedokteran Indonesia, vol. 57, pp. 205-211, 2007.

[15] E. Kumalasari and N. Sulistyani, "Aktivitas antifungi ekstrak etanol batang binahong (Anredera cordifolia (Tenore) Steen.) terhadap Candida albicans serta skrining fitokimia," Pharmaciana, vol. 1, pp. 51-62, 2011.

[16] F. Pasaribu, P. Sitorus, and S. Bahri, "Uji ekstrak etanol kulit buah manggis (Garcinia mangostana L.) terhadap penurunan kadar glukosa darah," Journal of Pharmaceutics and Pharmacology, vol. 1, pp. 1-8, 2012 . 
[17] B. Azizah and N. Salamah, "Standarisasi parameter non spesifik dan perbandingan kadar kurkumin ekstrak etanol dan ekstrak terpurifikasi rimpang kunyit," Pharmaciana, vol. 3, pp. 21-30, 2013.

[18] O. G. Echem and L. Kabari, "Heavy metal content in Bitter Leaf (Vernonia amygdalina) grown along heavy traffic routes in Port Harcourt," International Journal of Agricultural Chemistry, vol. 1, pp. 16, 2013.

[19] S. Audu, A. Taiwo, A. Ojuolape, A. Sani, A. Bukola, and I. Mohammed, "A study review of documented phytochemistry of Vernonia amygdalina (Family Asteraceae) as the basis for pharmacologic activity of plant extract," Journal of Natural Sciences Research, vol. 2, pp. 1-9, 2012.

[20] I. I. Ijeh and C. E. Ejike, "Current perspectives on the medicinal potentials of Vernonia amygdalina Del.," Journal of Medicinal Plants Research, vol. 5, pp. 1051-1061, 2011.

[21] N. Weerapreeyakul, A. Nonpunya, S. Barusrux, T. Thitimetharoch, and B. Sripanidkulchai, "Evaluation of the anticancer potential of six herbs against a hepatoma cell line," Chinese Medicine, vol. 7, pp. 1-7, 2012.

[22] J. Koul, S. Koul, C. Singh, S. Taneja, M. Shanmugavel, H. Kampasi, et al., "In vitro cytotoxic elemanolides from Vernonia lasiopus," Planta Medica, vol. 69, pp. 164-166, 2003.

[23] O. Owoeye, S. Yousuf, M. N. Akhtar, K. Qamar, A. Dar, E. O. Farombi, et al., "Another anticancer elemanolide from Vernonia amygdalina Del.," International Journal of Biological and Chemical Sciences, vol. 4, pp. 226-234, 2010.

[24] P. Pratheeshkumar and G. Kuttan, "Vernolide-A, a sesquiterpene lactone from Vernonia cinerea, induces apoptosis in B16F-10 melanoma cells by modulating p53 and caspase-3 gene expressions and regulating NF- $\mathrm{kB}$ - mediated bcl-2 activation," Drug and Chemical Toxicology, vol. 34, pp. 261-270, 2011.

[25] A. K. Pandurangan and S. Ganapasam, "Cytotoxic effect of luteolin on human colorectal cancer cell line (HCT-15): crucial involvement of reactive oxygen species," Middle East Journal of Cancer, vol. 4, pp. 175180, 2013.

[26] M. Kojima, T. Morisaki, N. Sasaki, K. Nakano, R. Mibu, M. Tanaka, et al., "Increased nuclear factor-kB activation in human colorectal carcinoma and its correlation with tumor progression," Anticancer Research, vol. 24, pp. 675-682, 2004.

[27] M. H. Park and J. T. Hong, "Roles of NF-кB in cancer and inflammatory diseases and their therapeutic approaches," Cells, vol. 5, p. 15, 2016.

[28] G.-Y. Liou and P. Storz, "Reactive oxygen species in cancer," Free Radical Research, vol. 44, pp. 1-31, 2010.

[29] P. Noguchi, R. Wallace, J. Johnson, E. Earley, S. O'brien, S. Ferrone, et al., "Characterization of WiDr: a human colon carcinoma cell line," In Vitro, vol. 15, pp. 401-408, 1979.

[30] A. Parrales and T. Iwakuma, "Targeting oncogenic mutant p53 for cancer therapy," Frontiers in Oncology, vol. 5, pp. 1-13, 2015.

[31] S. Elmore, "Apoptosis: a review of programmed cell death," Toxicologic Pathology, vol. 35, pp. 495-516, 2007.

[32] E. A. Slee, C. Adrain, and S. J. Martin, "Executioner caspase-3,-6, and-7 perform distinct, non-redundant roles during the demolition phase of apoptosis," Journal of biological Chemistry, vol. 276, pp. 7320-7326, 2001 . 